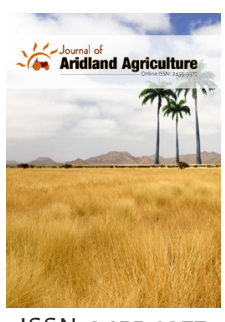

ISSN: $2455-9377$

\title{
Effect of four irrigation doses and four varieties on cotton bolls component, lint ratio and quality
}

\author{
Mohammed K. Darawsheh"*, Ioanna Kakabouki², Antigolena Folina², Stella \\ Karydogianni², Nikolaos Katsenios ${ }^{2}$, Charikleia Zisi
}

${ }^{1}$ Hellenic Agricultural Organization-Demeter/Institute of Industrial \& Forage Crops - National Cotton Classification Centre, 1st km Karditsa-Mitropili, 43100 Karditsa, Greece

${ }^{2}$ Agricultural University of Athens, Department of Crop Science. Lab of Agronomy. lera Odos 75, 11855, Athens, Votanikos, Greece

\begin{abstract}
Cotton is an industrial crop grown both in the north and in the Southern hemisphere and is one of the most profitable crops. Water is the resource that will be the most limited, especially for agriculture in the coming years. Irrigation availability is a critical factor in growing cotton in hot and dry climates. The experiments were performed in central Greece, in Palamas of the Karditsa region, for two years (2015-2016). The treatments were four different irrigation regimes, where IRR. 2 and IRR. 4 were deficient irrigations, IRR. 6, was a sufficient and IRR. 8, were overflow. Four varieties of cotton (Dp 419, Campo, Andromeda, Lider) were used where the effects of irrigation on cotton boll characteristics were recorded. The measurements made concerned the agronomic as well as the qualitative characteristics of the cotton bolls such as lint proportion, seed percentage, oil content, oil yield and micronaire. The oil content had positive correlation with the lint proportion and negative correlation with the seed percentage. In the both years of experiments the IRR. 2 and IRR. 8, irrigation regimes had negative effects while IRR. 4 and IRR. 6 had positive effects. Also among the varieties, Andromeda and Lider were the ones that stood out in both years.
\end{abstract}

*Corresponding Author Mohammed K. Darawsheh E-mail:m.daraouse@gmail. com

KEYWORDS: Agronomic characteristics, cotton bolls, irrigation regime, micronaire, varieties

\section{INTRODUCTION}

Cotton is an industrial crop grown both in the north and in the Southern hemisphere and is one of the most profitable crops [1]. Hence is an important crop for Greece as it represents 9\% of the country's total agricultural production. In the EU, Greece is by far the largest cotton supplier, producing 75-80 percent of the Community's total production [2]. In Greece, cotton is grown almost entirely in irrigated areas using drip irrigation techniques [2]. According to Chapagain et al. [3], water availability is associated with reduced cotton production, especially in areas with water availability problems.

The yields of cotton cultivation are inextricably linked to the amount of irrigation. It can also be affected not only by the amount of water but also by the way it is applied. Neelakanth et al. [4] compared surface and sub-surface drip irrigation systems and noted that sub- surface drip irrigation gave higher yield. Singh et al. [5] noted that regimes of deficit irrigation is an important factor that significantly affects performance. Moreover, Feike et al. [6] reported that the drip irrigation system showed a positive correlation with the yield and productivity of irrigation water.

Water is the resource that will be the most limited, especially for agriculture in the coming years [7]. According to Feike et al. [8], cotton cultivation has grown rapidly in the last 20 years, and this has led to a rapid increase in the irrigation water needs [6]. Irrigation regime (saturation, regular and deficit) affects yields and differentiates the best utilization of water. Zhang et al. [9] compared three irrigation regimes and concluded that deficit irrigation is the balanced system so that water is not wasted and efficiency is not significantly reduced.

Irrigation availability is a critical factor in growing cotton in hot and dry climates [10]. Growth and yield attributes of cotton were higher with $50 \%$ depletion of available soil moisture [11]. Kumar et al. [12], in India, used irrigation regime of $400 \mathrm{~mm}$ and $600 \mathrm{~mm}$, and the results showed that higher number of bolls per plant (37.08), boll weight ( $3.83 \mathrm{~g})$, seed cotton yield $\left(2568 \mathrm{~kg} \mathrm{ha}^{-1}\right)$, lint yield (734) $\mathrm{kg} \mathrm{ha}^{-1}$ ) and seed yield (1834 $\mathrm{kg} \mathrm{ha}^{-1}$ ) compared to $200 \mathrm{~mm}$ and did not differ significantly. 
Regarding seed yield of cotton, in a recent research it was found that it was reduced under limited irrigation compared to typical irrigation [13], as well as limited irrigation negatively affect the quality characteristics of cotton fibers [14].

Other studies have shown that an irrigation reduced by $20-25 \%$, compared to the amount of water of complete irrigation, did not significantly affect the yield of cotton cultivation [15-19]. On the other hand, it was reported that supplementary irrigation led to higher amounts of bolls, noodles, as well as yield [20]. Cotton is significantly affected by water stress during growth stages, with higher water use from flowering to seed formation stage [11]. In addition, Bilalis et al. [1] reported that germination and the first period of plant growth are the most important stages in the life cycle of cotton.

Besides agricultural interventions, the factor variety is also very important. In Pakistan, Khan et al. [21] compared eight cotton cultivars and four of them scored larger genetic potential for seed cotton yield. In Australia, six varieties were studied which over the years increased their production by $1.8 \%$ because of increased bolls $\mathrm{m}^{-2}$ [22]. In a sustainable context, improving irrigation services is key to agricultural production, whether irrigated or not. Cotton farming is facing a major problem, water consumption.

It is considered one of the expensive water intensive crops in Greece. Also, with climate change, cultivation zones are changing with new data being needed. The objectives of this study were: (i) to evaluate the effect of different water levels under drip irrigation on growth and yields, (ii) to measure the effect of different water regime under drip irrigation on fiber micronaire, bolls components (seed, lint \% exocarp) and seeds weight and oil content and (iii) to determine a base for the needs for water for 4 varieties that are cultivated in a large area throughout Greece.

\section{MATERIALS AND METHODS}

\section{Location and Experimental Design}

Two same cotton (Gossypium hirsutum L.) experiments were performed in central Greece, in Palamas (N $39^{\circ} 33^{\prime}-39^{\circ} 03^{\prime}$,
E $21^{\circ} 22^{\prime}-22^{\circ} 15^{\prime}$ ) of the Karditsa region, in 2015-2016. The experiments were followed split-plot design, with 4 main plots of different irrigations (IRR. 2, IRR. 4, IRR. 6, IRR. 8) and 16 subplots $\left(120 \mathrm{~m}^{2}\right)$ with four different varieties of cotton (Dp 419, Campo, Andromeda, Lider). Irrigation was carried out using a drip irrigation system and the details of irrigation are shown in Table 1.

The properties of the soil for the experimental field are presented in Table 2. The total experimental area was $1,920 \mathrm{~m}^{2}$, each main plot was $480 \mathrm{~m}^{2}$ and it was consisted of 4 sub-plots of an area of $120 \mathrm{~m}^{2}$. The mean temperature and the precipitation for 2015 were $22.27^{\circ} \mathrm{C}$ and $57.07 \mathrm{~mm}$ respectively, and for 2016 $21.95^{\circ} \mathrm{C}$ and $75.07 \mathrm{~mm}$. More details for the meteorological data during the experimental periods are presented in Figure 1.

In terms of the main characteristics of the varieties, the Dp 419 is characterized as medium-early, with excellent production potential of first growth, great adaptability to all environmental conditions. In addition, it delivers yield stability, high lint yield, and exceptional technological lint characteristics. Campo variety has ideal production potential, high yields, and high lint quality. The root system is deep, so soil moisture is maximized. Medium late variety, with excellent drought resistance. High adaptability to different soil and climatic conditions. High germination capacity, ideal variety for early sowing. A variety of new technology, developed for high lint yield. Andromeda is a medium-early variety, with excellent production potential, deeproot with high resistance to arid conditions and adaptability to all the soil types. Lider is also, a medium-early variety, highly adaptable to different soil types.

\section{Cultivation Practices}

Sowing took place on May 11, 2015 and May 13, 2016. The plants' emergence was done at 9 DAS on 2015 and at 11 DAS on 2016.Cotton was cultivated on conventional row spacing (96 $\mathrm{cm})$. Harvesting was done manually, for the first experiment at 133 DAP and 151 DAP, and for the second at 134 DAP and 153 DAP. Fertilization and weed control were performed. As for the fertilization, $400 \mathrm{~kg} \mathrm{ha}^{-1}$ (20-10-10) were applied before sowing and $100 \mathrm{~kg} \mathrm{ha}^{-1}$ potassium nitrate $\left(\mathrm{KNO}_{3}\right)(13-0-46)$

Table 1: The irrigation program for the two years (2015-2016)

\begin{tabular}{|c|c|c|c|c|c|c|c|}
\hline \multicolumn{8}{|c|}{ Irrigation Dose $\left(\mathrm{mm}^{3} \mathrm{ha}^{-1}\right)$} \\
\hline 2015 & $\begin{array}{l}41 \text { DAS } \\
\text { Bud }\end{array}$ & $\begin{array}{l}65 \text { DAS } \\
\text { Flowering }\end{array}$ & $\begin{array}{l}71 \text { DAS } \\
\text { Fruiting }\end{array}$ & $\begin{array}{c}108 \text { DAS Ball } \\
\text { Development }\end{array}$ & $\begin{array}{c}119 \text { DAS } \\
\text { Physiological Maturity }\end{array}$ & $\begin{array}{c}129 \text { DAS } \\
\text { Inception of Ball Opening }\end{array}$ & Total \\
\hline IRR. 2 & - & - & - & 400 & 600 & - & 1000 \\
\hline IRR. 4 & 400 & - & - & 400 & 600 & - & 1400 \\
\hline IRR. 6 & 400 & 400 & - & 600 & 600 & - & 2100 \\
\hline IRR. 8 & 400 & 400 & 500 & 600 & 500 & 500 & 2900 \\
\hline 2016 & $\begin{array}{l}73 \text { DAS } \\
\text { Bud }\end{array}$ & $\begin{array}{l}95 \text { DAS } \\
\text { Flowering }\end{array}$ & $\begin{array}{l}111 \text { DAS } \\
\text { Fruiting }\end{array}$ & $\begin{array}{l}129 \text { DAS Ball } \\
\text { Development }\end{array}$ & $\begin{array}{c}144 \text { DAS } \\
\text { Physiological Maturity }\end{array}$ & $\begin{array}{c}163 \text { DAS } \\
\text { Inception of Ball Opening }\end{array}$ & Total \\
\hline IRR. 2 & - & - & - & 400 & 600 & - & 1000 \\
\hline IRR. 4 & 400 & - & - & 400 & 600 & - & 1400 \\
\hline IRR. 6 & 400 & 400 & - & 600 & 600 & - & 2100 \\
\hline IRR. 8 & 400 & 400 & 500 & 600 & 500 & 500 & 2900 \\
\hline
\end{tabular}

DAS: days after sown 
after sowing weeds were controlled by hand- hoeing and by mechanical- hoeing.

\section{Measurements and Methods}

The 100 bolls randomly selected from each treatment to estimate the weight of bolls and bolls components. There were determined the weight of lint and seed per boll $(\mathrm{g})$, the total boll weight $(\mathrm{g})$, the lint and the seed percentage (\%), the 1000 seed weight $(\mathrm{g})$, exocarp weight per boll $(\mathrm{g})$, the lint weight per boll (g). In addition, the ratio between the lint of the boll, the seed and the boll, as well as between the exocarp and the boll

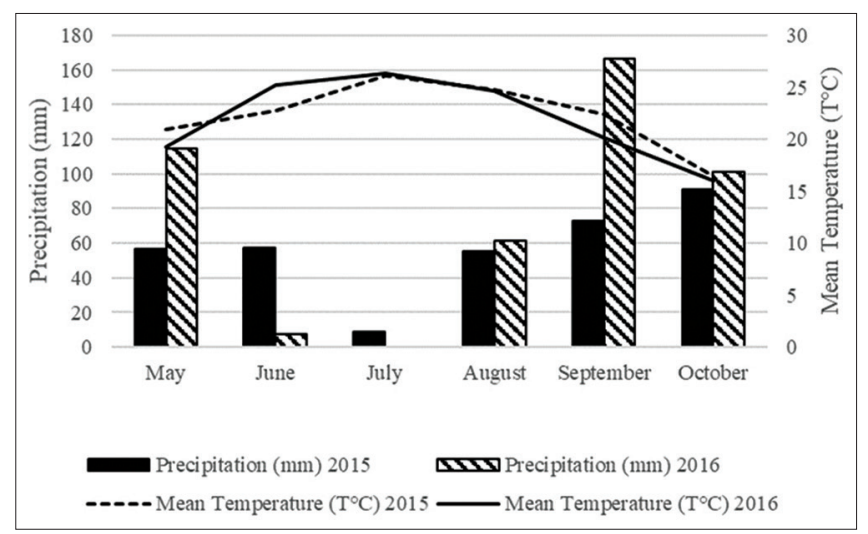

Figure 1: Meteorological data, mean temperature $\left({ }^{\circ} \mathrm{C}\right)$ and precipitation $(\mathrm{mm})$, during the experimental period, for both the years (2015-2016)

Table 2: Soil properties for the experimental field

\begin{tabular}{llllcccc}
\hline $\begin{array}{l}\text { Depth soil } \mathrm{CaCO}_{3} \% \\
\text { (layer) }\end{array}$ & $\mathrm{pH}$ & $\mathrm{P} \mathrm{ppm}$ & $\begin{array}{c}\mathrm{K}_{2} \mathrm{O} \\
100 \mathrm{~g}^{-1} \text { soil }\end{array}$ & & \multicolumn{3}{c}{ Mechanical analysis } \\
\hline $0-30$ & 1.26 & 8.2 & 17.5 & 5.1 & Sand\% & Silt \% & Clay \% \\
\hline $30-60$ & 3.36 & 8.4 & 5.5 & 0.7 & 39 & 45 & 16 \\
$60-90$ & 4.62 & 8.3 & 4.0 & 0.4 & 19 & 51 & 30 \\
\hline
\end{tabular}

were calculated. Finally, there were determined the micronaire the oil content (\%) and the oil yield from bolls $(\mathrm{g})$.

For the separation of lint and seed, a laboratory gin machine, saw ginning, was used [13]. The weights were measured using an analytical balance and expressed in grams. Micronaire determination followed international standards, ASTM D5867 and was carried out using a High-Volume Instrument (HVI1000), USTER Technologies AG. Also, the samples were airconditioned according to standard ASTM D1776 (Standard Practice for Conditioning and Testing Textiles). Regarding the oil determination, there was performed using a laboratory cold pressure machine.

\section{Statistical Analysis}

Analysis of variance was held on data using the STATISTICA (Stat Soft, 2011) logistic package as a split-plot design. For the significance of differences between treatments estimation, were used Tukey's test was used in significant level $(\mathrm{p}=0.05)$. The tests of correlation coefficients and linear regression by Statistica software were set at two levels with significance $(p=0.05)$ and remarkable significance $(\mathrm{p}=0.05)$.

\section{RESULTS}

The agronomic characteristics of cotton balls as well as weight lint \& seed per ball are presented in Table 3. In the first year, in all varieties, the IRR. 4 had not statistically significant difference with the IRR. 6 and IRR2 except of Campo variety. In Campo variety IRR4 and IRR6 did not had significantly difference between them and IRR2 with IRR8. The highest value was $6.80 \mathrm{~g}$ in the IRR. 4 in Lider variety. Also, in the second year the IRR. 8 had statistically significant difference with the other treatments in all varieties. The minimum value was $5.02 \mathrm{~g}$ in the IRR. 8 in Campo and Andromeda (Table 3).

Table 3: Characteristics of cotton bolls as affected by different irrigation systems and varieties for four varieties, for two years

\begin{tabular}{|c|c|c|c|c|c|c|c|c|}
\hline \multicolumn{5}{|c|}{ Average of boll weight (lint \& seed) (g) } & \multicolumn{4}{|c|}{ Average of boll weight with exocarp (g) } \\
\hline 2015 & Dp 419 & Campo & Andromeda & Lider & Dp 419 & Campo & Andromeda & Lider \\
\hline IRR. 2 & $5.01^{a}$ & $5.54^{\mathrm{a}}$ & $6.06^{a}$ & $6.30^{\mathrm{a}}$ & $6.67^{a}$ & $7.28^{a}$ & $7.87^{a}$ & $8.24^{a}$ \\
\hline IRR. 4 & $5.55^{\mathrm{ab}}$ & $6.24^{b}$ & $6.37^{a}$ & $6.80^{\mathrm{ab}}$ & $7.26^{b}$ & $8.17^{\mathrm{b}}$ & $8.33^{b}$ & $9.06^{b}$ \\
\hline IRR. 6 & $5.17^{\mathrm{a}}$ & $5.60^{\mathrm{ab}}$ & $6.00^{\mathrm{a}}$ & $6.12^{\mathrm{a}}$ & $6.92^{\mathrm{a}}$ & $7.41^{\mathrm{a}}$ & $7.96^{\mathrm{a}}$ & $8.15^{\mathrm{a}}$ \\
\hline IRR. 8 & $4.73^{c}$ & $5.03^{\mathrm{a}}$ & $5.06^{b}$ & $5.23^{c}$ & $6.20^{\mathrm{a}}$ & $6.46^{d}$ & $6.65^{d}$ & $6.91^{d}$ \\
\hline 2016 & Dp 419 & Campo & Andromeda & Lider & Dp 419 & Campo & Andromeda & Lider \\
\hline IRR. 2 & $5.47^{a}$ & $5.77^{a}$ & $6.04^{a}$ & $6.50^{a}$ & $7.15^{a}$ & $7.66^{a}$ & $7.95^{a}$ & $8.49^{\circ}$ \\
\hline IRR. 4 & $5.63^{a}$ & $5.78^{a}$ & $5.85^{a}$ & $6.46^{a}$ & $7.27^{b}$ & $7.55^{b}$ & $7.70^{\mathrm{b}}$ & $8.55^{b}$ \\
\hline IRR. 6 & $5.62^{a}$ & $5.79^{a}$ & $5.84^{a}$ & $6.45^{a}$ & $7.28^{b}$ & $7.56^{b}$ & $7.70^{\mathrm{b}}$ & $8.54^{b}$ \\
\hline IRR. 8 & $5.15^{b}$ & $5.02^{b}$ & $5.02^{b}$ & $5.53^{b}$ & $6.78^{c}$ & $6.55^{c}$ & $6.61^{c}$ & $7.32^{\circ}$ \\
\hline$F_{i r r i g}$ & & $44.02^{\text {*** }}$ & & & & $53.27^{\text {** }}$ & & \\
\hline$F_{\text {variety }}^{\text {irrig }}$ & & $58.86^{* * *}$ & & & & $65.97^{* * *}$ & & \\
\hline$F_{\text {year }}$ & & ns & & & & ns & & \\
\hline$F_{\text {irrig } x \text { variety }}$ & & ns & & & & ns & & \\
\hline$F_{\text {irrig } \times \text { year }}$ & & $4.13^{* *}$ & & & & $2.94^{*}$ & & \\
\hline$F_{\text {variety } x \text { year }}^{I \text { IfPlg year }}$ & & $5.27^{* *}$ & & & & $6.03^{\text {** }}$ & & \\
\hline$F_{\text {irrig } x \text { variety } x \text { year }}$ & & ns & & & & ns & & \\
\hline
\end{tabular}

F-test ratios are from ANOVA. Different letters within a column indicate significant differences according to Tukey's test. Significance levels:

${ }^{*} p<0.05 ; * * p<0.01 ; * * * p<0.001 ;$ ns, not significant ( $p>0.05$ ). IRR: irrigation 
Furthermore, in the average of boll weight with exocarp, in the 2015, Dp 419 differs IRR4 with the rest of the treatments and for Campo, Andromeda and Lider IRR2 did not significantly differs with IRR6. But in the 2016 the IRR. 4 had not statistically significant difference with the IRR. 6 in all varieties. The highest value 2015 was $9.06 \mathrm{~g}$ in the IRR. 4 in Lider and the lowest was $6.46 \mathrm{~g}$ in the IRR. 8 in Campo. The fact that is observed is that in IRR. 8 in all varieties the lowest values appeared (Table 3).

Additional, in the Lint proportion for the first year, the IRR. 8 had statistically significant difference with the other treatments in the Dp 419, in the Campo, in the Andromeda and in the Lider (Table 4). On the other hand, in the second year the IRR. 2 had not statistically significant difference with the IRR. 6 in all varieties. The highest value was $45.63 \%$ in the fourth irrigation system in the 2016 and the lowest value was $37.88 \%$ in the third irrigation system in the 2015, in the Dp 419 variety respectively.
Furthermore, in the micronaire in both years was significantly affected by irrigation and variety. In 2015, Dp 419 campo and Lider were not statistically differences for IRR4 and IRR 6. The highest value was 4.97 in the IRR. 4 in the Lider variety and the lowest value was 4.43 in Andromeda variety during 2016 (Table 4). Furthermore, in the lint weight per boll in the 2015, in Dp 419, Campo and Lider Andromeda variety the IRR. 6 had not statistically significant difference with the IRR2 and IRR. 8, On the other hand, in the second year various presented between Dp 419 and Lider is presented variation, as shown in Table 4. In Adromeda variety IRR2 was significantly differs with IRR4, IRR6 and IRR8. The highest value was 2.83 in the second irrigation system in the Lider and the lowest was 1.95 in the IRR. 8 in the first year. In the second year the values recorded were clearly higher in all four varieties (Table 4).

In the 1000 seed weight in the both years of experiment all the varieties were different from each other in terms of the

Table 4: Characteristics of cotton bolls as affected by different irrigation systems and varieties

\begin{tabular}{|c|c|c|c|c|c|c|c|c|c|c|c|c|}
\hline \multirow[t]{2}{*}{2015} & \multicolumn{4}{|c|}{ Lint proportion (\%) } & \multicolumn{4}{|c|}{ Micronaire } & \multicolumn{4}{|c|}{ Lint weight per boll } \\
\hline & Dp 419 & Campo & Andromeda & Lider & Dp 419 & Campo & Andromeda & Lider & Dp 419 & Campo & Andromeda & Lider \\
\hline IRR. 2 & $39.53^{a}$ & $39.48^{\mathrm{a}}$ & $40.14^{\mathrm{a}}$ & $40.76^{a}$ & $4.45^{a}$ & $4.50^{\mathrm{a}}$ & $4.50^{a}$ & $4.45^{a}$ & $1.98^{\mathrm{a}}$ & $2.19^{a}$ & $2.43^{a}$ & $2.57^{\mathrm{a}}$ \\
\hline IRR. 4 & $39.35^{a}$ & $40.68^{a}$ & $40.47^{a}$ & $41.60^{\mathrm{a}}$ & $4.70^{b}$ & $4.83^{a b}$ & $4.50^{a}$ & $4.70^{b}$ & $2.18^{b}$ & $2.54^{b}$ & $2.58^{b}$ & $2.83^{b}$ \\
\hline IRR. 6 & $37.88^{a}$ & $38.38^{a}$ & $39.27^{a}$ & $38.70^{a}$ & $4.50^{b}$ & $4.83^{b}$ & $4.80^{b}$ & $4.50^{b}$ & $1.96^{\mathrm{a}}$ & $2.15^{\mathrm{a}}$ & $2.36^{a}$ & $2.37^{a}$ \\
\hline IRR. 8 & $41.31^{\mathrm{b}}$ & $43.21^{b}$ & $43.94^{b}$ & $42.08^{b}$ & $4.97^{\mathrm{a}}$ & $4.73^{c}$ & $4.73^{b}$ & $4.97^{\mathrm{a}}$ & $1.95^{\mathrm{a}}$ & $2.17^{\mathrm{a}}$ & $2.22^{\mathrm{a}}$ & $2.20^{a}$ \\
\hline 2016 & Dp 419 & Campo & Andromeda & Lider & Dp 419 & Campo & Andromeda & Lider & Dp 419 & Campo & Andromeda & Lider \\
\hline IRR. 2 & $42.43^{a}$ & $43.06^{\mathrm{ac}}$ & $43.53^{b}$ & $41.79^{a}$ & $4.83^{a}$ & $4.60^{a}$ & $4.60^{a}$ & $4.83^{a}$ & $2.32^{\mathrm{a}}$ & $2.49^{a}$ & $2.63^{a}$ & $2.72^{a}$ \\
\hline IRR. 4 & $40.20^{b}$ & $40.90^{b}$ & $41.00^{\mathrm{a}}$ & $40.80^{a}$ & $4.97^{b}$ & $4.87^{\mathrm{ab}}$ & $4.43^{a b}$ & $4.97^{b}$ & $2.37^{a}$ & $2.42^{b}$ & $2.45^{b}$ & $2.69^{a}$ \\
\hline IRR. 6 & $42.16^{a}$ & $41.78^{a}$ & $41.87^{a}$ & $41.70^{a}$ & $4.67^{b}$ & $4.83^{b}$ & $4.77^{c}$ & $4.67^{a}$ & $2.37^{a}$ & $2.42^{b}$ & $2.45^{b}$ & $2.69^{a}$ \\
\hline IRR. 8 & $44.63^{c}$ & $45.63^{c}$ & $45.56^{c}$ & $44.12^{b}$ & $4.77^{a}$ & $4.63^{a}$ & $4.43^{a b}$ & $4.77^{a}$ & $2.30^{b}$ & $2.29^{c}$ & $2.29^{b}$ & $2.44^{b}$ \\
\hline$F_{i r r i g}$ & & $9.44^{* * *}$ & & & & $21.88^{* * *}$ & & & & $50.33^{* * *}$ & & \\
\hline$F_{\text {variety }}$ & & $156.38^{* * *}$ & & & & $10.86^{* * *}$ & & & & $25.90^{* * *}$ & & \\
\hline$F_{\text {year }}$ & & $397.79^{* * *}$ & & & & ns & & & & $53.06^{* * *}$ & & \\
\hline$F_{\text {irrig } x \text { variety }}$ & & $3.22^{* *}$ & & & & $11.70^{\text {** }}$ & & & & $2.18^{*}$ & & \\
\hline$F_{\text {irrig } x \text { year }}$ & & $9.30^{* * *}$ & & & & $4.07^{* *}$ & & & & $6.03^{* * *}$ & & \\
\hline$F_{\text {variety } x \text { year }}$ & & $11.40^{* * *}$ & & & & $9.82^{* * *}$ & & & & $10.54^{* * *}$ & & \\
\hline$F_{\text {irrig } x \text { variety } x \text { year }}$ & & ns & & & & $2.58^{*}$ & & & & ns & & \\
\hline
\end{tabular}

F-test ratios are from ANOVA. Different letters within a column indicate significant differences according to Tukey's test. Significance levels:

$* p<0.05 ; * * p<0.01 ; * * * p<0.001$; ns, not significant ( $p>0.05$ ). IRR: irrigation

Table 5: Characteristics of cotton bolls as affected by different irrigation systems and varieties

\begin{tabular}{|c|c|c|c|c|c|c|c|c|c|c|c|c|}
\hline \multirow[t]{2}{*}{2015} & \multicolumn{4}{|c|}{1000 seed weight $(\mathrm{g})$} & \multicolumn{4}{|c|}{ Seed weight per boll (g) } & \multicolumn{4}{|c|}{ Exocarp weight per boll (g) } \\
\hline & Dp 419 & Campo & Andromeda & Lider & Dp 419 & Campo & Andromeda & Lider & Dp 419 & Campo & Andromeda & Lider \\
\hline IRR. 2 & $9.95^{a}$ & $10.21^{a b}$ & $10.20^{a}$ & $11.52^{\mathrm{a}}$ & $3.03^{\mathrm{a}}$ & $3.35^{a}$ & $3.63^{a}$ & $3.73^{a}$ & $1.65^{\mathrm{a}}$ & $1.74^{\mathrm{a}}$ & $1.81^{\mathrm{a}}$ & $1.94^{\mathrm{a}}$ \\
\hline IRR. 4 & $9.45^{b}$ & $11.44^{b}$ & $11.19^{\mathrm{b}}$ & $11.67^{\mathrm{a}}$ & $3.37^{b}$ & $3.70^{\mathrm{a}}$ & $3.79^{b}$ & $3.98^{b}$ & $1.71^{\mathrm{a}}$ & $1.93^{b}$ & $1.97^{\mathrm{b}}$ & $2.26^{a b}$ \\
\hline IRR. 6 & $10.45^{c}$ & $10.32^{\mathrm{ab}}$ & $10.61^{\mathrm{a}}$ & $11.57^{\mathrm{a}}$ & $3.21^{b}$ & $3.45^{\mathrm{a}}$ & $3.64^{\mathrm{a}}$ & $3.75^{\mathrm{a}}$ & $1.76^{\mathrm{a}}$ & $1.81^{\mathrm{b}}$ & $1.96^{\mathrm{b}}$ & $2.03^{b}$ \\
\hline IRR. 8 & $9.71^{d}$ & $9.40^{c}$ & $9.53^{c}$ & $10.50^{b}$ & $2.78^{c}$ & $2.86^{b}$ & $2.83^{c}$ & $3.03^{c}$ & $1.48^{b}$ & $1.43^{c}$ & $1.60^{\mathrm{c}}$ & $1.68^{c}$ \\
\hline 2016 & Dp 419 & Campo & Andromeda & Lider & Dp 419 & Campo & Andromeda & Lider & Dp 419 & Campo & Andromeda & Lider \\
\hline IRR. 2 & $9.91^{\mathrm{a}}$ & $10.83^{a}$ & $10.72^{\mathrm{a}}$ & $11.36^{\mathrm{a}}$ & $3.15^{\mathrm{a}}$ & $3.29^{a}$ & $3.41^{a}$ & $3.78^{a}$ & $1.69^{a}$ & $1.89^{a}$ & $1.91^{\mathrm{a}}$ & $1.99^{a}$ \\
\hline IRR. 4 & $11.04^{b}$ & $10.57^{a}$ & $11.79^{\mathrm{a}}$ & $11.94^{\mathrm{a}}$ & $3.25^{b}$ & $3.37^{b}$ & $3.40^{a}$ & $3.76^{b}$ & $1.65^{\mathrm{a}}$ & $1.76^{\mathrm{b}}$ & $1.85^{\mathrm{ab}}$ & $2.04^{a b}$ \\
\hline IRR. 6 & $9.87^{a}$ & $10.50^{\mathrm{a}}$ & $10.37^{a}$ & $11.57^{\mathrm{a}}$ & $3.24^{b}$ & $3.36^{b}$ & $3.39^{a}$ & $3.75^{\mathrm{b}}$ & $1.64^{\mathrm{a}}$ & $1.77^{\mathrm{b}}$ & $1.86^{\mathrm{b}}$ & $2.09^{b}$ \\
\hline IRR. 8 & $9.31^{c}$ & $9.32^{\mathrm{c}}$ & $9.40^{b}$ & $10.42^{b}$ & $2.85^{c}$ & $2.73^{c}$ & $2.72^{b}$ & $3.09^{c}$ & $1.63^{\mathrm{a}}$ & $1.54^{c}$ & $1.59^{c}$ & $1.78^{c}$ \\
\hline$F_{i r r i q}$ & & $63.12^{* * *}$ & & & & $36.57^{\text {*** }}$ & & & & $58.38^{* * *}$ & & \\
\hline$F_{\text {variety }}$ & & $68.71^{* * *}$ & & & & $58.68^{* * *}$ & & & & $86.20^{* * *}$ & & \\
\hline$F_{\text {year }}$ & & ns & & & & ns & & & & $7.58^{* *}$ & & \\
\hline$F_{\text {irrig } x \text { variety }}^{\text {year }}$ & & $2.97^{* *}$ & & & & $2.87^{* *}$ & & & & ns & & \\
\hline$F_{\text {irrig } x \text { year }}$ & & ns & & & & ns & & & & $3.16^{*}$ & & \\
\hline$F_{\text {variety } x \text { year }}$ & & $3.89^{*}$ & & & & $7.95^{* * *}$ & & & & ns & & \\
\hline$F_{\text {irrig } x \text { variety } x \text { year }}$ & & $5.11^{* * *}$ & & & & ns & & & & ns & & \\
\hline
\end{tabular}

F-test ratios are from ANOVA. Different letters within a column indicate significant differences according to Tukey's test. Significance levels:

$* p<0.05 ; * * p<0.01 ; * * * p<0.001 ;$ ns, not significant ( $p>0.05$ ). IRR: irrigation 
results of the statistical analysis concerning the effect of the different irrigation systems (Table 5). The highest value was $11.94 \mathrm{~g}$ in the IRR. 6 in Lider variety and the lowest was $9.31 \mathrm{~g}$ in the fourth irrigation system in the Dp 419 variety in the 2016 (Table 5). Moreover, in the seed weight per boll in the first year of experiment in the Dp 419 the IRR. 4 had not statistically significant difference with the IRR. 6, in the Andromeda the IRR. 2 had not statistically significant difference with the IRR. 2 the same was true in the Lider. In contrast in the 2016 only the DP 419 had the same results as in 2015 in terms of statistical analysis in the other varieties, various differences were observed as shown in Table 3. The highest value was $3.98 \mathrm{~g}$ in the IRR. 4 and in the Lider variety in the first year and the lowest was $2.72 \mathrm{~g}$ in the IRR. 8 in the Andromeda variety in the second year. Also, in the exocarp weight per boll Andromeda was no different from Lider in both years of the experiment. For Dp 419 vareit, during second year were not significant differences among irrigation doses. The highest value was $2.26 \mathrm{~g}$ in the IRR. 4 in Lider variety and the lowest was 1.43 in the IRR. 8 in the Campo variety (Table 5).

In the Table 6 are presented the quality characteristics as well as oil content. In the first year the Dp 419 had not statistically significant difference with the Andromeda and the Campo had not statistically significant difference with the Lider, the same was true and in the second year of experiment. The Lider variety had the highest values compared to the other varieties in all the different irrigation systems in both years and the Dp 419 had the lowest values. The highest value was $16.84 \%$ in the fourth system of irrigation in the Lider in the 2016 and the lowest was $13.50 \%$ in the IRR. 2 in the Campo in 2015.

Moreover, in the oil yield per ball Dp 419 had statistically significant difference with the other varieties the same was

Table 6: Quality characteristics of cotton bolls as affected by different irrigation systems and varieties

\begin{tabular}{|c|c|c|c|c|c|c|c|c|c|c|c|c|}
\hline \multirow[t]{2}{*}{2015} & \multicolumn{4}{|c|}{ Oil content (\%) } & \multicolumn{4}{|c|}{ Oil yield per boll $(\mathrm{g})$} & \multicolumn{4}{|c|}{ Seed percentage (\%) } \\
\hline & Dp 419 & Campo & Andromeda & Lider & Dp 419 & Campo & Andromeda & Lider & Dp 419 & Campo & Andromeda & Lider \\
\hline IRR. 2 & $13.83^{\mathrm{ab}}$ & $13.50^{\mathrm{a}}$ & $14.03^{a}$ & $14.17^{a}$ & $0.42^{a}$ & $0.45^{\mathrm{a}}$ & $0.51^{a}$ & $0.53^{a}$ & $60.47^{a}$ & $60.52^{a}$ & $59.86^{a}$ & $59.24^{a}$ \\
\hline IRR. 4 & $14.13^{a}$ & $14.40^{b}$ & $14.70^{b}$ & $15.13^{b}$ & $0.48^{a}$ & $0.53^{b}$ & $0.56^{b}$ & $0.60^{b}$ & $60.65^{b}$ & $59.32^{b}$ & $59.53^{b}$ & $58.40^{b}$ \\
\hline IRR. 6 & $14.23^{b c}$ & $15.10^{c}$ & $15.33^{b c}$ & $15.49^{c}$ & $0.46^{b}$ & $0.52^{b}$ & $0.56^{b}$ & $0.58^{b}$ & $62.12^{b}$ & $61.62^{b}$ & $60.73^{b}$ & $61.30^{\mathrm{b}}$ \\
\hline IRR. 8 & $14.89^{c}$ & $15.32^{c}$ & $15.90^{c}$ & $16.16^{d}$ & $0.41^{c}$ & $0.44^{c}$ & $0.45^{c}$ & $0.49^{c}$ & $58.69^{c}$ & $56.79^{c}$ & $56.06^{c}$ & $57.92^{c}$ \\
\hline 2016 & Dp 419 & Campo & Andromeda & Lider & Dp 419 & Campo & Andromeda & Lider & Dp 419 & Campo & Andromeda & Lider \\
\hline IRR. 2 & $14.22^{\mathrm{ab}}$ & $14.12^{\mathrm{a}}$ & $14.38^{a}$ & $14.84^{a}$ & $0.45^{\mathrm{a}}$ & $0.46^{a}$ & $0.49^{a}$ & $0.56^{a}$ & $57.57^{a}$ & $56.94^{a}$ & $56.47^{a}$ & $58.21^{a}$ \\
\hline IRR. 4 & $14.68^{a}$ & $15.31^{b}$ & $15.78^{b}$ & $15.90^{b}$ & $0.48^{b}$ & $0.52^{b}$ & $0.54^{b}$ & $0.60^{b}$ & $57.94^{b}$ & $58.29^{b}$ & $58.21^{b}$ & $58.38^{b}$ \\
\hline IRR. 6 & $14.76^{b c}$ & $15.67^{c}$ & $15.56^{b c}$ & $16.10^{c}$ & $0.48^{b}$ & $0.53^{b}$ & $0.53^{b}$ & $0.61^{b}$ & $57.84^{a}$ & $58.22^{\mathrm{a}}$ & $58.13^{a}$ & $58.30^{a}$ \\
\hline IRR. 8 & $15.41^{c}$ & $16.03^{c}$ & $16.36^{c}$ & $16.84^{d}$ & $0.44^{c}$ & $0.44^{c}$ & $0.45^{c}$ & $0.52^{c}$ & $55.37^{c}$ & $54.37^{c}$ & $54.96^{c}$ & $55.06^{c}$ \\
\hline$F_{i r r i g}$ & & $87.39^{* * *}$ & & & & & $70.45^{* * *}$ & & & $9.44^{* * *}$ & & \\
\hline$F_{\text {variety }}$ & & $220.25^{* * *}$ & & & & & $52.62^{* * *}$ & & & $156.38^{* * *}$ & & \\
\hline$F_{\text {year }}$ & & $155.56^{* * *}$ & & & & & ns & & & $397.79^{* \star *}$ & & \\
\hline$F_{\text {irrigx }}$ & & $5.16^{* * *}$ & & & & & ns & & & $3.22^{* *}$ & & \\
\hline$F_{\text {irrig } x \text { year }}$ & & ns & & & & & $2.94^{*}$ & & & $9.30^{* * *}$ & & \\
\hline$F_{\text {variety } x \text { year }}$ & & ns & & & & & ns & & & $11.40^{* * *}$ & & \\
\hline 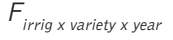 & & ns & & & & & ns & & & ns & & \\
\hline
\end{tabular}

F-test ratios are from ANOVA. Different letters within a column indicate significant differences according to Tukey's test. Significance levels:

$* p<0.05 ; * * p<0.01 ; * * * p<0.001 ;$ ns, not significant $(p>0.05)$. IRR: irrigation

Table 7: The ratio of cotton boll as affected by different irrigation systems and varieties

\begin{tabular}{|c|c|c|c|c|c|c|c|c|c|c|c|c|}
\hline \multirow[t]{2}{*}{2015} & \multicolumn{4}{|c|}{ Ratio lint boll-1 } & \multicolumn{4}{|c|}{ Ratio seed boll-1 } & \multicolumn{4}{|c|}{ Ratio exocarp boll-1 } \\
\hline & Dp 419 & Campo & Andromeda & Lider & Dp 419 & Campo & Andromeda & Lider & Dp 419 & Campo & Andromeda & Lider \\
\hline IRR. 2 & $0.30^{\mathrm{a}}$ & $0.30^{a}$ & $0.31^{\mathrm{a}}$ & $0.31^{a}$ & $0.50^{a}$ & $0.46^{a}$ & $0.46^{a}$ & $0.45^{\mathrm{a}}$ & $0.25^{\mathrm{a}}$ & $0.24^{a}$ & $0.23^{a}$ & $0.24^{a}$ \\
\hline IRR. 4 & $0.30^{\mathrm{a}}$ & $0.31^{\mathrm{a}}$ & $0.31^{\mathrm{a}}$ & $0.31^{\mathrm{a}}$ & $0.46^{b}$ & $0.45^{\mathrm{a}}$ & $0.45^{\mathrm{a}}$ & $0.44^{b}$ & $0.24^{b}$ & $0.24^{a}$ & $0.24^{b}$ & $0.25^{b}$ \\
\hline IRR. 6 & $0.28^{b}$ & $0.29^{a}$ & $0.30^{b}$ & $0.29^{b}$ & $0.46^{b}$ & $0.47^{b}$ & $0.46^{a}$ & $0.46^{a}$ & $0.25^{a}$ & $0.24^{a}$ & $0.25^{b}$ & $0.25^{b}$ \\
\hline IRR. 8 & $0.31^{b}$ & $0.34^{b}$ & $0.33^{b}$ & $0.32^{b}$ & $0.45^{\mathrm{a}}$ & $0.44^{a}$ & $0.43^{b}$ & $0.44^{b}$ & $0.24^{b}$ & $0.22^{b}$ & $0.24^{b}$ & $0.24^{a}$ \\
\hline 2016 & Dp 419 & Campo & Andromeda & Lider & Dp 419 & Campo & Andromeda & Lider & Dp 419 & Campo & Andromeda & Lider \\
\hline IRR. 2 & $0.32^{\mathrm{a}}$ & $0.32^{\mathrm{a}}$ & $0.33^{a}$ & $0.33^{a}$ & $0.44^{a}$ & $0.43^{a}$ & $0.43^{a}$ & $0.45^{a}$ & $0.24^{a}$ & $0.25^{a}$ & $0.24^{a}$ & $0.23^{a}$ \\
\hline IRR. 4 & $0.33^{b}$ & $0.32^{\mathrm{a}}$ & $0.32^{b}$ & $0.32^{\mathrm{a}}$ & $0.45^{b}$ & $0.45^{b}$ & $0.44^{\mathrm{a}}$ & $0.44^{a}$ & $0.23^{b}$ & $0.23^{b}$ & $0.24^{a}$ & $0.24^{b}$ \\
\hline IRR. 6 & $0.31^{b}$ & $0.30^{\mathrm{a}}$ & $0.31^{b}$ & $0.32^{\mathrm{a}}$ & $0.45^{b}$ & $0.45^{b}$ & $0.44^{\mathrm{a}}$ & $0.44^{\mathrm{a}}$ & $0.23^{b}$ & $0.23^{b}$ & $0.24^{a}$ & $0.24^{b}$ \\
\hline IRR. 8 & $0.34^{a}$ & $0.35^{b}$ & $0.34^{a}$ & $0.34^{b}$ & $0.42^{\mathrm{a}}$ & $0.42^{\mathrm{a}}$ & $0.41^{b}$ & $0.42^{b}$ & $0.24^{a}$ & $0.23^{b}$ & $0.24^{a}$ & $0.24^{b}$ \\
\hline$F_{i r r i q}$ & & $9.75 * * *$ & & & & $5.44 * *$ & & & & $3.843 *$ & & \\
\hline$F_{\text {variety }}$ & & $155.48 * * *$ & & & & $59.27 * * *$ & & & & ns & & \\
\hline$F_{\text {year }}$ & & $387.10 * * *$ & & & & $153.10 * * *$ & & & & ns & & \\
\hline$F_{\text {irrig } x \text { variety }}$ & & $5.02 * * *$ & & & & $2.25^{*}$ & & & & $3.48 * * *$ & & \\
\hline$F_{\text {irrig } x \text { year }}$ & & $14.24 * * *$ & & & & $3.04 *$ & & & & $4.98 * *$ & & \\
\hline$F_{\text {variety } x \text { year }}$ & & $15.76^{* * *}$ & & & & $4.18 * *$ & & & & $5.52 * *$ & & \\
\hline$F_{\text {irrig } x \text { variety } x \text { year }}$ & & & & & & ns & & & & ns & & \\
\hline
\end{tabular}

F-test ratios are from ANOVA. Different letters within a column indicate significant differences according to Tukey's test. Significance levels:

${ }^{*} p<0.05 ;{ }^{*} p<0.01 ; * * * p<0.001 ;$ ns, not significant ( $p>0.05$ ). IRR: irrigation 
true in the second year. The highest value was $0.61 \mathrm{~g}$ in IRR. 6 in the Lider in the 2016 and the lowest was $0.41 \mathrm{~g}$ in the IRR. 8 in the Dp 419 in 2015 (Table 6). The Dp 419 had the lowest values and the Lider had the highest values in the both years. It is worth emphasizing that in the IRR. 8 in both years but also in the four varieties the smallest oil yields per boll were recorded in the RR 4 (Table 6). Also, in the seed percentage in the first year of experiment the IRR. 4 had not statistically significant difference with the IRR. 6 in all varieties. But, in the 2016 the IRR. 2 had not statistically significant difference with the IRR. 6. The values ranged from 56.06 to $62.69 \%$ in the 2015 and from 54.37 to $58.38 \%$ in the 2016 . The lowest values recorded in the RR 4 in the both years of experiment and in all varieties.

Concerning the ratio lint boll-1 the Campo had statistically significant difference with the other varieties in the 2015 (Table 7). But in the 2016, the Dp 419 had not statistically significant difference with the Andromeda and the Campo had not statistically significant difference with the Lider (Table 7).

In 2016 the IRR. 4 had not statistically significant difference with the IRR. 6 in the four varieties. The highest value was 0.35 in the IRR. 8 in the Campo in the 2016 and the lowest was 0.28 in the IRR. 6 in the Dp419 variety in 2015. Also, in the ratio seed boll-1 Dp 419 variety had the highest values in the both years. The highest value was 0.50 in the IRR. 2 in the DP 419 in 2015 and the lowest was 0.41 in the IRR. 8 in Andromeda variety in 2016. Furthermore, in the ratio seed boll-1 the highest value was 0.47 in the IRR. 6 in Campo in 2015 and the lowest was 0.41 in the IRR. 8, in the Andromeda in 2016 (Table 7). The first year all varieties had statistically significant difference between them. On the other hand, in 2016 the Dp 419 had not statistically significant difference with the Campo and the Andromeda had not statistically significant difference with the Lider. The values shown in the ratio exocarp boll-l were similar in all irrigation systems as in all four varieties. The values ranged from 0.22 to 0.25 in the both years of experiment. The lowest value was 0.22 in the IRR. 8, in the Campo in 2015 (Table 7).

\section{DISCUSSION}

Darawsheh et al. [13], reported that the different irrigation (typical and limited) had not effect in the average of boll weight with exocarp in the cotton. In contrast, in our results the different irrigation regimes had effect in the average of boll weight with exocaro in all varieties. Similar results were recorded in the average of boll weight (lint \& seed) and in the lint weight per boll where the weight decreases as the irrigation regimes increase. Yagmur et al. [23] also highlighted the negative impact of irrigation on the weight of cotton boll. In addition it is reported that the mid-season irrigation is positively correlated with boll retention [24]. As shown in the Table 8 the average of boll weight with exocarp had negative correlation with the lint percentage $(r=-0.28, p=0.01)$. That could be explained because, as the weight increases, the lint percentage decreases and vice versa. Concerning the lint percentage, Onder et al. [25] said that the lowest quantities of water had positive effect in the lint proportion. Contrariwise, in our study the highest lint

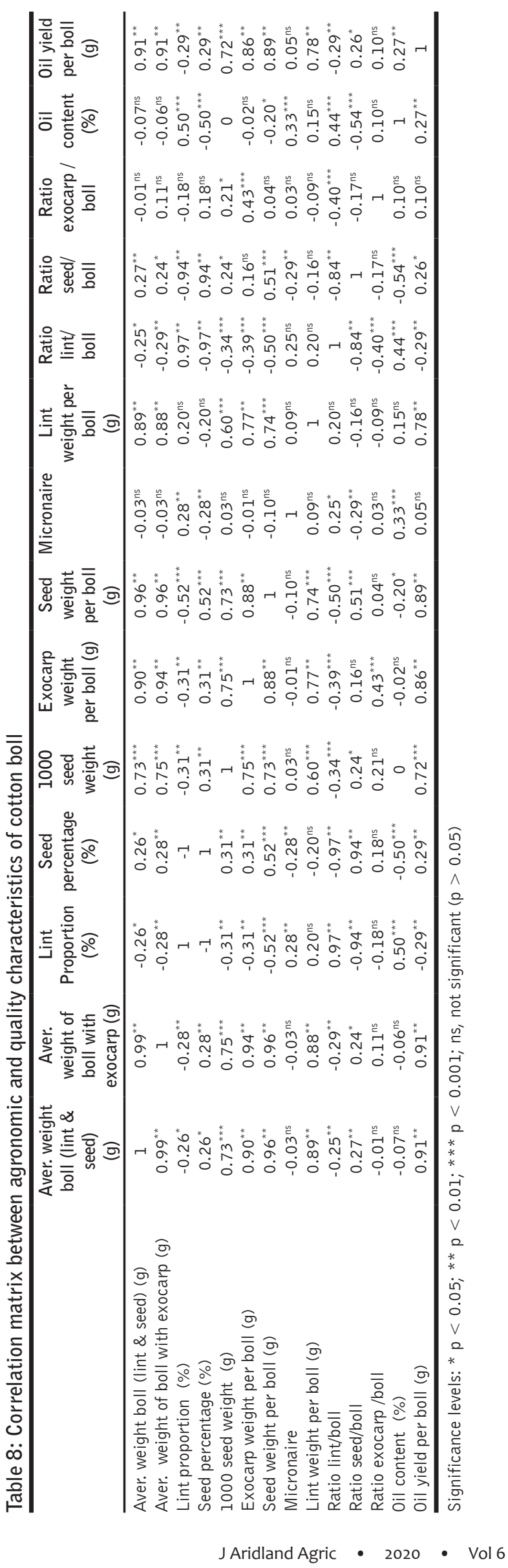


percentage recorded in the highest regime of irrigation. Similar results was shown in other studies in which they observed the highest lint yield in the highest irrigation regime [26]. In addition, according to Witt et al. [27] fiber quality in upland species was decreased when the irrigation level was low. The above differences are due to the climatic conditions as well as the varieties used in each study. The lint proportion had negative correlation with the oil yield per boll $(\mathrm{r}=-0.29, \mathrm{p}=0.01)$, (Table 8). According to Onder et al. [25] the highest value of seed cotton recorded in the maximum irrigation in contrast with our study where the lowest value recorded in highest quantities of irrigation. Darawsheh et al. [13] noticed that the different irrigation system had negative effect on the 1000 seed weight. The same was true in our results concerning the weight of a 1000 seeds because there was a downward trend in certain irrigation and more specifically in the highest of all the varieties studied in the two years of the experiment.

The 1000 weight per boll had positive correlation with the lint weight per boll $(\mathrm{r}=0.60, \mathrm{p}=0.001)$ but negative correlation with the lint proportion $(\mathrm{r}=-0.31, \mathrm{p}=0.01)$ as shown in the Table 8 . Onder et al. [25] reported that the seed weight per boll affected by different irrigation regimes. In particular, it highlighted the fact that the highest seed weight was recorded at the highest regime of irrigation. In contrast to our study and the four varieties grown at the regime of over-irrigation, the lowest values appeared. The seed weight per boll had negative correlation with oil content $(r=-0.20, p=0.05)$ but positive correlation with the oil yield per boll $(\mathrm{r}=0.89, \mathrm{p}=0.01)$, (Table 8$)$. Moreover, in accordance to the present study, Pinnamaneni et al. [7] said that seed oil content was affected by irrigation. According to Pettigrew et al. [28], the seed percentage decreases with irrigation of cotton cultivation compared to cases where it was not irrigated. In general, over-irrigation did not have any positive effect in any variety in the percentage of seed in both years that the experiment took place. Andromeda and Lider were the varieties that reacted best to all irrigation regimes in both years.

\section{CONCLUSION}

In conclusion the different irrigation regimes effected the agronomic as well as the qualitive characteristics of the cotton boll. In particular, regimes IRR. 2 and IRR. 8 were the treatments that negatively affected in most characteristics in all varieties in both years. It is worth emphasizing that at the IRR. 8 regime the quality characteristics were higher in all varieties. In most of the cases, regimes of IRR 4 and IRR 6 gave the highest values for the agronomic and quality characteristics of the cotton bolls. The varieties that stood out in both years were Andromeda and Lider.

\section{REFERENCES}

1. Bilalis DJ, Katsenios N, Efthimiadou A, Karkanis A, Efthimiadis P. Investigation of pulsed electromagnetic field as a novel organic presowing method on germination and initial growth stages of cotton. Electromagnetic Biology and Medicine. 2012;31(2):143-150. doi:1 $0.3109 / 15368378.2011 .624660$.

2. Karagiannis $\mathrm{G}$ (2004). The EU cotton policy regime and the implications of the proposed changes for producer welfare. FAO Commodity and Trade Policy Research Working Paper, 9. http://www.
fao.org/es/ESC/

3. Chapagain AK, Hoekstra AY, Savenije HHG, Gautam R. The water footprint of cotton consumption: an assessment of the impact of worldwide consumption of cotton products on the water resources in the cotton producing countries. Ecological Economics. 2006;60(1): 186-203.

4. Neelakanth JK, Rajkumar S, Gundlur SS, Dasar GV. Effect of surface and sub-surface drip irrigation system on seed cotton in Vertisols of Malaprabha command in Northern Karnataka. Journal of Pharmacognosy and Phytochemistry. 2019;8(2):956-958.

5. Singh Y, Rao SS, Regar PL. Deficit irrigation and nitrogen effects on seed cotton yield, water productivity and yield response factor in shallow soils of semi-arid environment. Agricultural Water Management. 2010;97(7):965-970.

6. Feike T, Khor LY, Mamitimin Y, Ha N, Li L, Abdusalih N, Xiao H, Doluschitz R. Determinants of cotton farmers' irrigation water management in arid Northwestern China. Agricultural Water Management. 2017;187:1-10. doi:10.1016/j.agwat.2017.03.012.

7. Pinnamaneni SR, Saseendra AS, Sui R, Bellaloui N, Reddy KN. Effect of irrigation and planting geometry on cotton fiber quality and seed composition. Journal of Cotton Research. 2020;1-12. DOI: https:// doi.org/10.21203/rs.3.rs-76100/v1

8. Feike T, Mamitimin YLiL, Doluschitz R. Development of agricultural land and water use and its driving forces along the Aksu and Tarim River, PR China. Environmental Earth Sciences. 2015;73(2):517-531.

9. Zhang D, Luo Z, Liu S, Li W, Dong H. Effects of deficit irrigation and plant density on the growth, yield and fiber quality of irrigated cotton. Field Crops Research. 2016;197:1-9.

10. Papastylianou PT, Argyrokastritis IG. Effect of limited drip irrigation regime on yield, yield components, and fiber quality of cotton under Mediterranean conditions. Agricultural Water Management. 2014;142:127-134. doi:10.1016/j.agwat.2014.05.005.

11. Gomaa M, Ibrahim AE, Emara MA, Kattosh AA. Effect of water stress and fertilization on cotton productivity under calcareous soil conditions. Zagazig Journal of Agricultural Research. 2019;46(2):251264.

12. Kumar R, Pareek NK, Rathore VS, Nangiya V. Effect of irrigation and nitrogen application on water productivity and performance of Cotton (Gossypium sp.). Journal of Soil and Water Conservation. 2019;18(3): 282-287.

13. Darawsheh MK, Kakabouki I, Roussis I, Bilalis DJ. Cotton Response to Planting Patterns under Effect of Typical and Limited Irrigation Regime. Notulae Botanicae Horti Agrobotanici Cluj-Napoca. 2019;47(4):1206-1214. doi:10.15835/nbha47411712.

14. Darawsheh MK. Cotton fiber quality parameters response to cultivation system as influenced by limited and normal irrigation. Journal of Food, Agriculture \& Environment. 2010;8 (2):527-530.

15. Wanjura DF, Upchurch DR, Mahan JR, Burke JJ. Cotton yield and applied water relationships under drip irrigation. Agricultural Water Management. 2002; 55(3):217-237.

16. Ertek A, Kanber R. Effects of different drip irrigation programs on the boll number and shedding percentage and yield of cotton. Agricultural. Water Management. 2003;60(1):1-11.

17. Dagdelen N, Yilmaz E, Sezgin F, Gürbüz T. Water-yield relation and water use efficiency of cotton (Gossypium hirsutum L.) and second crop corn (Zea mays L.) in western Turkey. Agricultural Water Management. 2006;82(1-2):63-85.

18. Karam F, Lahoud R, Masaad R, Daccache A, Mounzer O, Rouphael Y. Water use and lint yield response of drip irrigated cotton to the length of irrigation season. Agricultural Water Management. 2006;85: 287-295.

19. Kang Y, Wang R, Wan S, Hu W, Jiang S, Liu S. Effects of different water levels on cotton growth and water use through drip irrigation in an arid region with saline ground water of Northwest China. Agricultural Water Management. 2012;109: 117-126.

20. Pettigrew WT. Moisture deficit effects on cotton lint yield, yield components, and boll distribution. Agronomy Journal. 2004 a;96(2): 377-383

21. Khan NU, Marwat KB, Hassan G, Farhatullah SB, Makhdoom K Ahmad W, Khan HU. Genetic variation and heritability for cotton seed, fiber and oil traits in Gossypium hirsutum L. Pakistan Journal of Botany. 2010;42(1):615-625.

22. Kilby CR, Tan DK, Duggan BL. Yield components of high-yielding Australian cotton cultivars. Cotton Research Journal. 2013;5(2):117- 
130.

23. Yagmur E, Gurel A, Oren Y, Izci B, Edreva A, Hakerlerler H, Hayta S, Akdemir $\mathrm{H}$, Yildiz-Aktas. Effects of different drought applications and potassium doses on cotton yield and fiber quality. Research Journal of Agricultural and Environmental Management. 2014;3(1):60-67.

24. Schaefer CR, Ritchie GL, Bordovsky JP, Lewis K, Kelly, B. Irrigation Timing and Rate Affect Cotton Boll Distribution and Fiber Quality. Agronomy Journal. 2018;110(3): 922-931. doi:10.2134/ agronj2017.06.0360

25. Onder M, Akiscan Y, Onder S, Mert M. Effect of different irrigation regime water level on cotton yield and yield components. African Journal of Biotechnology. 2009;8(8):1536-1544.
26. Lascano RJ, Baumhardt RL, Goebel1 TS, Baker JT, Gitz III DC. Irrigation Termination Thermal Time and Amount on Cotton Lint Yield and Fiber Quality. Open Journal of Soil Science. 2017;7(9): 216-234. https:// doi.org/10.4236/ojss.2017.79016

27. Witt TW, Ulloa M, Schwartz RC, Ritchie GL. Response to deficit irrigation of morphological, yield and fiber quality traits of upland (Gossypium hirsutum L.) and Pima (G. barbadense L.) cotton in the Texas High Plains. Field Crops Research. 2020;249:1-10. doi:10.1016/j.fcr.2020.107759

28. Pettigrew WT. Moisture deficit effects on cotton lint yield, yield components and boll distribution. Agronomy Journal. 2004;96(2):377-382 